\title{
A CONVIVÊNCIA NA ESCOLA E O BULLYING ENTRE ESTUDANTES NOS ENSINOS FUNDAMENTAL II E MÉDIO
}

\author{
Carmen Lúcia Dias (UNOESTE)* \\ Terezinha Ferreira da Silva Colombo (UNESP)** \\ Alessandra de Morais (UNESP)***
}

\section{RESUMO}

Este artigo teve como objetivo analisar as percepções de estudantes de uma escola particular de Educação Básica sobre o maltrato entre iguais, no que se refere à sua incidência e características, e oferecer dados prévios de diagnóstico para que possam ser planejados programas de intervenção voltados para a prevenção e erradicação do bullying no ambiente educativo. Participaram da pesquisa 508 estudantes, 309 do Ensino Fundamental II e 199 do Ensino Médio, os quais responderam a um questionário que avalia o tipo de bullying presente na comunidade educativa. Os resultados sinalizam que há indícios de situações de maus-tratos na escola pesquisada, sendo considerável o número daqueles que passam por esse tipo de situação seja como alvo, agente ou telespectador. Sobre a quem pedem ajuda quando se sentem vitimizados, observa-se que recorrem mais à família e aos colegas, vários não falam nada a ninguém e por último pedem ajuda aos professores, apesar de os indicarem como aqueles que principalmente deveriam fazer algo para solucionar esse problema. A escola precisa reconhecer a existência do fenômeno para que esteja consciente de seus prejuízos para a personalidade e desenvolvimento socioeducacional dos estudantes. Também é necessário instrumentalizar seus profissionais para observação, identificação, diagnóstico, intervenção e encaminhamentos assertivos.

Palavras-chave: Bullying. Diagnóstico. Convivência escolar. Ensinos Fundamental II e Médio.

\section{ABSTRACT \\ COEXISTENCE AT SCHOOL AND BULLYING AMONG STUDENTS IN ELEMENTARY SCHOOL II AND HIGH SCHOOL}

This paper had as purpose to analyze the students' perceptions, of a private school of

\footnotetext{
* Doutora em Educação e Pós-Doutoranda pela Universidade Estadual Paulista (UNESP), campus de Marília/SP. Docente do Mestrado em Educação da Universidade do Oeste Paulista (UNOESTE), Presidente Prudente/SP. Pesquisadora do Grupo de Estudos e Pesquisas em Educação Moral (GEPEM/Unicamp/UNESP). E-mail: kkaludias@gmail.com

** Doutoranda em Educação pela Universidade Estadual Paulista (UNESP), campus de Marília/SP. Diretora Pedagógica de Ensino Fundamental II e Médio do Colégio Criativo. Pesquisadora do Grupo de Estudos e Pesquisas em Educação Moral (GEPEM/Unicamp/UNESP). E-mail: tfcolombo@terra.com.br

*** Doutora em Educação pela Universidade Estadual Paulista (UNESP), campus de Marília/SP. Professora Assistente Doutora do Departamento de Psicologia da Educação e do Programa de Pós-Graduação em Educação da Faculdade de Filosofia e Ciências da UNESP, campus de Marília/SP. Pesquisadora do Grupo de Estudos e Pesquisas em Educação Moral (GEPEM/ Unicamp/UNESP). E-mail: alemorais.shimizu@gmail.com
} 
Elementary Education, about the maltreatment among equals, regarding its incidence and characteristics and, offer previous diagnostic data so that intervention programs can be planned aiming the prevention and eradication of bullying in the educational environment. The research participants were 508 students, 309 of Elementary Education II and 199 of High school, which answered a questionnaire that assess the type of bullying present in the educational community. The results indicate that there are indications of maltreatment situations in the researched school, with a considerable number of those who go through this type of situation being target, agent, or viewer. Regarding whom they ask for help when feeling victimized, it was observed that they resort more to family and colleagues, many do not say anything to anyone, and finally some ask for help to teachers; despite indicate them as those who, mainly, should do something to solve this problem. The school must recognize the existence of this phenomenon, being aware of the losses to the personality and socio-educational development of students. It is also necessary to equip its employees for the observation, identification, diagnosis, intervention and assertive guiding.

Keywords: Bullying. Diagnosis. Coexistence at school. Elementary School II and High School.

\section{RESUMEN}

\section{LA CONVIVENCIA EN LA ESCUELA Y EL BULLYING ENTRE LOS ESTUDIANTES EN LA EDUCACIÓN PRIMARIA Y SECUNDARIA}

Este artículo tuvo como objetivo analizar las percepciones de estudiantes, de una escuela privada de Educación Básica, sobre el maltrato entre iguales, en lo que se refiere a su incidencia y características, y ofrecer datos previos de diagnóstico, para que puedan ser planeados programas de intervención dirigidos a la prevención y erradicación del bullying en ambiente educativo. Participaron de la investigación 508 estudiantes, 309 de la Educación Primaria y 199 de la Educación Secundaria, los cuales respondieron a una encuesta que evalúa el tipo de bullying presente en la comunidad educativa. Los resultados señalan que hay indicios de situaciones de malos tratos en la escuela investigada, siendo considerable el número de aquellos que pasan por ese tipo de situación sea como blanco, agente, o espectador. Sobre a quién piden ayuda cuando se sienten victimizados, se observa que recurren más a la familia y a los colegas, varios no hablan nada a nadie, y por último piden ayuda a los profesores; a pesar de les marcar como aquellos que principalmente deberían hacer algo para solucionar ese problema. La escuela precisa reconocer la existencia del fenómeno, así que, esté consciente de sus perjuicios para la personalidad y desenvolvimiento socio educacional de los estudiantes. También es necesario instrumentalizar sus profesionales para observación, identificación, diagnóstico, intervención e encaminamientos asertivos. Palabras-clave: Bullying. Diagnóstico. Convivencia escolar. Educación Primaria y Secundaria.

\section{Introdução}

A violência e a hostilidade vividas entre as pessoas na sociedade têm gerado medo e muita indignação. E a escola não fica excluída de tais situações lamentáveis, injustas e agressivas que transpõem muros adentro servindo de experiências que deflagram ainda mais sentimentos de intolerância, de vingança e de dificuldade de compreender e respeitar o outro. 
Uma pesquisa realizada pelo instituto Data Popular em parceria com o Sindicato dos Professores do Ensino Oficial do Estado de São Paulo (2013), após ouvir 1400 professores no primeiro semestre de 2013, aponta que dois em cada dez alunos da rede pública paulista admitem já ter cometido algum tipo de violência nas escolas. Apesar disso, a pesquisa revelou que $40 \%$ dos docentes, $81 \%$ dos pais e $83 \%$ dos estudantes afirmaram que suas escolas não realizam atualmente nenhuma campanha contra a violência. Este fenômeno no mundo contemporâneo tem merecido destaque por ser complexo e necessita ser discutido em suas bases, portanto as práticas individuais e coletivas que dão espaço e lugar para que possivelmente tal fenômeno ocorra são o ponto de partida para que se pense em uma campanha pela paz nas escolas. Nessa direção, o conjunto de normas de convivência subjacente ao interior da escola, se analisado e discutido, poderá revelar meios eficazes para que se reverta o cenário escolar como produtor e reprodutor de violência.

Retomando o parágrafo inicial deste texto, conceituar o termo violência faz-se necessário, contudo, esta repercute de forma generalizada em nossa sociedade e sua abrangência requer amplitude de definição. Desta forma, serão consideradas definições que abarcam múltiplas dimensões, sendo

[...] uma delas, os casos que envolvem danos físicos que indivíduos podem cometer contra si próprios ou contra os outros. Outra dimensão é o conjunto de restrições, que se dá no plano das instituições e que impede que os indivíduos usufruam plenamente de seus direitos fundamentais, abrangendo, portanto, as modalidades da violência simbólica e institucional. A terceira dimensão corresponde às incivilidades e microviolências, que costumam ser as modalidades mais recorrentes e comuns no cotidiano. (ABRAMOVAY, 2005, p. 3).

Cano (2005) afirma que a violência pode decorrer de múltiplas formas, dentre elas das relações típicas entre os atores escolares, ou seja, entre professores e alunos e vice-versa, e o que tem aparecido cada vez mais são as intimidações exercidas pelos alunos mais fortes sobre os mais fracos, conhecidas também como bullying. E para Debarbieux (2002), as pesquisas apontam que a violência nas escolas deve ser analisada sob o espectro macro e microssociológico, com causas exógenas, relativas ao bairro, ao sistema econômico, a falhas familiares e falta de políticas públicas; e endógenas, referentes ao interior das escolas, que se apresentam com diferentes graus de organização/desorganização local que podem interferir no clima escolar.

Complementando, Charlot (2005) ressalta uma distinção entre a violência, que ataca a lei com o uso da força ou com a ameaça de usá-la (roubos, vandalismos, crimes etc.), a transgressão, comportamento adverso ao regulamento interno da instituição escolar, e a incivilidade, que contradizem a boa convivência (empurrões, humilhações, insultos, grosserias, falta de respeito, interpelações etc). Há que ressaltar que muitas vezes, hoje, essa distinção não se faz nítida, os três tipos podem ser encontrados em comportamentos cotidianos. Há casos em que a incivilidade quando ocorre de estudante(s) para estudante de forma agressiva, intencional, repetidamente e sem motivação aparente, causando sofrimento ao outro, podendo configurar-se como bullying, segundo a Associação Brasileira Multiprofissioanal de Proteção à Infância e à Adolescência (COSTA; LIMA, 2011, p. 175). Efetiva-se, portanto, uma forma contundente de utilização de poder sobre o outro, intimidando a vítima.

Aquino (1996) questiona se as microviolências não estariam sinalizando também uma necessidade legítima de transformações no interior das relações escolares e, em particular, nas relações professor-aluno. Não estaríamos diante de um novo sujeito histórico, que se recusa a práticas fortemente arraigadas no cotidiano escolar, assim como uma tentativa de apropriação da escola de outra maneira, mais aberta, mais fluída, mais democrática? Corroboramos com o autor que essa é uma questão que deve estar presente em todo processo de reflexão conjunta da comunidade escolar, bem como da família e da sociedade.

Outro ponto a se considerar é o jovem que caracteriza esse novo sujeito. Isso nos leva a pensar num período de transição entre a puberdade e o estado adulto do desenvolvimento humano, lembrando que a adolescência é uma construção cultural, cuja presença e forma de manifestação podem variar de sociedade para sociedade. 
Sob a ótica da psicanálise, Aberastury (1980) nos revela que as modificações psicológicas que ocorrem neste período, correspondentes de modificações corporais, levam o adolescente a uma nova relação com os pais e com o mundo que o rodeia. Isto só se torna possível com a elaboração do conflito pela perda de seu corpo infantil, da sua identidade infantil.

Todas as modificações corporais incontroláveis, como os imperativos do mundo externo, exigem do adolescente novas pautas de convivência, são vividas ao princípio como uma invasão. Isto o leva, como defesa, a reter muito dos ganhos infantis, ainda que também coexistam o prazer e o afã de realmente ocupar seu novo 'status' [...] Estas mudanças, nas quais perde seu esquema corporal e sua identidade de criança, implicam a busca de uma nova identidade, que se vai construindo em um plano consciente e inconsciente [...] (ABERASTURY, 1980, p. 25).

Portanto, esse é um período que requer um olhar minucioso às relações que se estabelecem entre os jovens, entre estes e o mundo adulto nas mais diversas instâncias.

Esse olhar cuidadoso não levaria à ausência de conflitos? Por certo que não! A não-violência, que a paz requer, "considera o conflito como estando no cerne das relações entre as pessoas e entre os grupos humanos" (TOGNETTA, [2002], p. 109). A princípio o conflito pode ser resultante das relações humanas como meio de desenvolvimento; por outro lado, uma sociedade baseada em relações de poder que privilegiam a competição, a ambição, $o$ egoísmo, a falta de diálogo, entre outros, pode levar à violência propriamente dita. E isso se repercute em todas as instâncias sociais, entre as quais a instituição escolar.

Rigorosamente falando, o poder não existe; existem sim práticas ou relações de poder. O que significa dizer que o poder é algo que se exerce, que se efetua, que funciona. E funciona como uma maquinaria, como uma máquina social que não está situada $\mathrm{em}$ um lugar privilegiado ou exclusivo, mas se dissemina por toda a estrutura social e não é um objeto, uma coisa, mas uma relação (FOUCAULT, 1997, p. 26-27).

Não raro, temos assistido episódios de violência nas escolas e, como mencionado acima, em pesquisa realizada em 2013, dois em cada dez alunos da rede pública paulista admitem já ter cometido algum tipo de violência nas escolas (SINDICATO DOS PROFESSORES DO ENSINO OFICIAL DO ESTADO DE SÃO PAULO, 2013). Isso nos leva a discorrer sobre um tema recorrente que também já se institui no universo escolar, o bullying, objeto da presente investigação.

\section{Caracterizando o bullying}

Bullying é uma palavra de origem inglesa, utilizada para se referir a um fenômeno que tem como característica o desejo consciente e deliberado de maltratar outra pessoa e colocá-la sob tensão, o que inclui o emprego de comportamentos agressivos e antissociais.

Apesar de em diferentes países poderem ser empregados outros termos para conceituar esses mesmos tipos de comportamentos, no Brasil adotamos o termo que é utilizado na maioria dos países: bullying.

Bully, enquanto nome, é traduzido como 'valentão', 'tirano', e como verbo, 'brutalizar', 'tiranizar', 'amedrontar'. Dessa forma, a definição de bullying, é compreendida como um subconjunto de comportamentos agressivos sendo caracterizado por sua natureza repetitiva e por desequilíbrio de poder [...] sem motivação evidente adotado por um ou mais alunos contra outro(s), causando dor, angústia e sofrimento [...] levando-os à exclusão, além de danos físicos, morais e materiais [...] (FANTE, 2005, p. 28-29).

Díaz-Aguado (2006, 2015) define o bullying escolar como um tipo específico de violência entre pares, que um aluno pode sofrer ou exercer em determinado momento, que contempla quatro características, as quais qualificam sua gravidade: 1) abrange diferentes tipos de condutas: provocações, ameaças, intimidações, agressões físicas, isolamento sistemático, ofensas, dentre outras; 2) não se restringe a um acontecimento isolado, repete-se e prolonga-se durante certo tempo, produzindo-se em contextos nos quais as pessoas são obrigadas a se encontrar frequentemente, como na escola; 3 ) é provocado por um indivíduo, na maior parte das vezes, apoiado pelo grupo, tendo como alvo uma vítima que se encontra indefesa e não consegue por si mesma sair da situação; 4) a situação tende 
a se manter devido à ignorância ou passividade das pessoas que circundam os agressores e as vítimas, sem intervirem de modo direto.

Assim, fazem parte desse fenômeno três categorias (FANTE, 2005): as vítimas, os agressores e os espectadores. As vítimas podem ser caracterizadas como: vítima típica, considerada frágil, pouco sociável, que sofre repetidamente com comportamentos agressivos de outros e não dispõe de recursos para reagir ou cessar as condutas do agressor; vítima provocadora, que se caracteriza como aquela que atrai reações agressivas pelo seu modo de agir no grupo, como pessoa de costumes irritantes, causando tensões no ambiente e sendo ineficaz para lidar com as agressões sofridas; vítima agressora, aquela que reproduz o que sofreu, que procura "bodes expiatórios", indivíduos mais frágeis que ela, na tentativa de transferir os maus-tratos sofridos. $\mathrm{O}$ agressor é aquele que vitimiza os mais fracos e expressa pouca empatia. Geralmente se apresenta mais forte física e/ou psicologicamente que seus companheiros de classe e suas vítimas, podendo ser da mesma idade ou um pouco mais velho. Já o espectador apenas assiste as manifestações do agressor sem praticá-las, convive com o problema adotando a lei do silêncio, por medo de se transformar em alvo para o agressor; contudo, mesmo não sofrendo as agressões, se sente inseguro e incomodado.

Novos paradigmas estão sendo construídos acerca das formas de violência (AVILÉS MARTÍNEZ, 2013), destacando-se dentre outros, o cyberbullying, como uma maneira de agressão não presencial, utilizando mensagens, páginas da web, gravações ou e-mail e ferramentas disponíveis na internet para amedrontar, difamar, humilhar, ameaçar e ridicularizar as vítimas. Este meio parece ser mais viável e seguro para o agressor, que se vê protegido para as suas investidas contra a vítima que recebe o maltrato à distância; o bullying homofóbico, que se caracteriza pela prática ofensiva contra as pessoas que se diferenciam quanto à orientação sexual; e o bullying racista que poderá ocorrer com sujeitos de outras etnias ou minorias por meio de insultos ou agressões racistas. Portanto, o fenômeno bullying, mediante sua intensidade, poderá causar no indivíduo prejuízos de ordem intelectual, emocional e social.
Esses fenômenos discutidos até o momento devem ser colocados em perspectiva, pois, de acordo com Debarbieux (2002), esta será uma forma de gestores institucionais, professores, famílias e governantes responsáveis pela promoção de políticas públicas destinadas a esse fim garantirem medidas de prevenção adequadas. $\mathrm{O}$ autor acredita que se qualquer tipo de violência é construída, então ela poderá ser desconstruída, sendo previsível, pois foi construída socialmente. E ainda, os atores, ao contrário do que se imagina, não são impotentes, ou mesmo manipulados por forças externas, contudo, dependem de um olhar adulto que promova a rejeição às ameaças ou às agressões que acontecem no dia a dia escolar.

Preocupados com a manifestação dos diferentes tipos de violência (bullying, microviolências, incivilidades etc.), autores de diversos países, como Abramovay (2005), Avilés Martinez (2013), Debarbieux (2002), Díaz-Aguado (2015), Fante (2005), Fernández (2005), Ruotti, Alves e Cubas (2006) e Tognetta e Vinha (2011), vêm discutindo e propondo ações norteadoras e experiências que podem contribuir com os membros da comunidade escolar no auxílio de soluções mais apropriadas para a realidade de cada escola. É prática recorrente entre os autores a indicação de um levantamento diagnóstico que aponte e descreva os tipos de violência que ocorrem na instituição, isso para a tomada de decisão quanto à solução e prevenção de tais conflitos.

Fante (2005) sinaliza a importância da reflexão pedagógica voltada para a temática dos valores humanos (a ética, a moral e a cidadania), visando à constituição de um trabalho que permita que os indivíduos vivenciem situações em que o respeito, a tolerância, a cooperação sejam pano de fundo das relações interpessoais rumo a uma educação para a paz. Com relação ao fenômeno bullying, Fante e Pedra (2008) acreditam que a prevenção começa pelo conhecimento. A escola precisa reconhecer a existência do fenômeno para que esteja consciente de seus prejuízos para a personalidade e desenvolvimento socioeducacional dos estudantes. Também é preciso instrumentalizar seus profissionais para observação, identificação, diagnóstico, intervenção e encaminhamentos assertivos, e conduzir o tema 
à discussão com a comunidade escolar, traçando estratégias preventivas capazes de fazer frente ao fenômeno. Além do engajamento de todos, é preciso contar com a ajuda de consultores externos, como especialistas no tema, psicólogos e assistentes sociais. É imprescindível o estabelecimento de parcerias com conselhos tutelares, delegacias da Criança e do Adolescente, promotorias públicas, vara da Infância e Juventude, promotorias da Educação, dentre outros (FANTE; PEDRA, 2008).

Tognetta (2011) afirma que a qualidade do ambiente sociomoral se configura como uma das questões primordiais para se levar em conta no processo de implantação de proposta "antibullying". Para que esse ambiente seja de qualidade, a autora sugere que se abra espaço para que meninos e meninas verbalizem seus pensamentos e sentimentos na resolução de conflitos.

Vinha e colaboradores (2011) apontam o círculo restaurativo na escola como estratégia de intervenção para a resolução de conflitos. Cabe esclarecer que ele advém do âmbito jurídico, a justiça restaurativa. Os círculos restaurativos, no contexto educativo, dão o direito à fala e à melhoria dos relacionamentos e o fortalecimento de laços comunitários, com foco na reparação de danos, na autorresponsabilização e na participação efetiva de todos os envolvidos: alunos, professores, comunidade, família e rede de apoio. As autoras indicam que os círculos restaurativos acontecem em três momentos distintos: o pré-círculo, em que as partes são ouvidas de forma individual pelos mediadores ou facilitadores; o círculo, momento em que cada parte pode colocar seus sentimentos em relação ao ocorrido e estabelecer compromisso de resolução e reparação do conflito, e que seja bom para os envolvidos; o pós-círculo, que ocorre por volta de um mês após a realização do círculo, para verificação do cumprimento dos fatos acordados.

Complementando essas ações, no Brasil foi publicada, no Diário Oficial da União, a Lei $n^{\circ}$ 13.185/2015, sancionada pela Presidente da República, que obriga escolas e clubes a adotarem medidas de prevenção e combate ao bullying.
Art. $4^{\circ}$ Constituem objetivos do Programa referido no caput do art. $1^{\circ}$ :

I - prevenir e combater a prática da intimidação sistemática (bullying) em toda a sociedade;

II - capacitar docentes e equipes pedagógicas para a implementação das ações de discussão, prevenção, orientação e solução do problema;

III - implementar e disseminar campanhas de educação, conscientização e informação;

IV - instituir práticas de conduta e orientação de pais, familiares e responsáveis diante da identificação de vítimas e agressores;

V - dar assistência psicológica, social e jurídica às vítimas e aos agressores;

VI - integrar os meios de comunicação de massa com as escolas e a sociedade, como forma de identificação e conscientização do problema e forma de preveni-lo e combatê-lo;

VII - promover a cidadania, a capacidade empática e o respeito a terceiros, nos marcos de uma cultura de paz e tolerância mútua;

VIII - evitar, tanto quanto possível, a punição dos agressores, privilegiando mecanismos e instrumentos alternativos que promovam a efetiva responsabilização e a mudança de comportamento hostil;

IX - promover medidas de conscientização, prevenção e combate a todos os tipos de violência, com ênfase nas práticas recorrentes de intimidação sistemática (bullying), ou constrangimento físico e psicológico, cometidas por alunos, professores e outros profissionais integrantes de escola e de comunidade escolar. (BRASIL, 2015, p. 1).

Observa-se que essa lei, com sua importância e suporte para a efetivação de ações proativas, não garante por si só a erradicação da violência, visto que ainda é preciso a constituição de uma cultura antiviolência, que poderá ser fomentada pela educação desde o ensino infantil.

É, portanto, a base moral que devemos trabalhar se quisermos erradicar a presença do bullying e ter garantias suficientes de sucesso. Avilès Martinez (2013) assegura que para uma prática efetiva de combate à violência e ao abuso de poder será necessário um trabalho conjunto com a sociedade, a família e a escola. 


\section{Educação moral: um caminho para a convivência de paz}

Ao iniciarmos este tópico, ressaltamos como ponto de reflexão o papel da escola numa proposta de educação para a paz. Num primeiro momento, cabe repensar o contexto escolar e como este pode suprir e otimizar espaços para que os protagonistas se desenvolvam de forma autônoma e aprendam a conviver, a respeitar o outro. Para isso,

[...] é preciso ensinar os alunos a pensar, e é impossível aprender a pensar num regime autoritário. Pensar é procurar por si próprio, é criticar livremente e é demonstrar de forma autônoma. O pensamento supõe o jogo livre das funções intelectuais e não o trabalho sob pressão e a repetição verbal [...] uma educação do pensamento, da razão e da própria lógica, é necessária e condição primeira da educação da liberdade. (PIAGET, [2002], p. 122-123).

Ainda para Piaget [2002], essa educação da liberdade intelectual pressupõe a cooperação entre pares e a livre discussão que encaminhe para educar o espírito crítico do aluno, ou seja, deve haver o exercício de uma vida social na própria escola que favoreça a autonomia moral e a liberdade de pensamento.

Cabe esclarecer que para se falar em mudança no seio da escola é imprescindível dizer dos atores que dela fazem parte, quais sejam, gestores, professores, alunos, funcionários e famílias. Esses personagens constituem a cultura escolar e é com eles que se conta com a mudança para a cultura da não violência. Ferramentas são necessárias para que se inicie esse processo como, por exemplo, um investimento da escola que incentive e dê a formação continuada em serviço dos professores; crie espaços para discussões coletivas que envolvam a equipe escolar e a comunidade para que juntos busquem alternativas para enfrentamentos/resolução de seus conflitos (TOGNETTA et al, 2010).

Já dizia Piaget (1998), em 1932, que a escola é lócus privilegiado para que a criança aprenda a conviver, tendo em vista ser este espaço constituído por seus pares. Nessa perspectiva, adentrar-se-á no espaço das atividades escolares, a sala de aula propriamente dita, como meio de vivenciar noções morais que contemplem a cooperação, a solidariedade, o respeito mútuo, a justiça, enfim, a sala de aula como ambiente democrático que proporcione todas essas vivências.

Nessa direção, com a intenção de se construir escolas cada vez mais democráticas, Puig (2004, p. 95) nos apresenta as práticas morais, dentre as quais as procedimentais, que são "todas aquelas situações que convidam ao diálogo, à compreensão e ao intercâmbio construtivo de razões". Estas se apresentam em assembleias de classe, resolução de conflitos e a mediação escolar, sessões de debate, consideração de questões curriculares e vitais, discussão de dilemas, exercícios de role playing (dramatização) e os exercícios de compreensão crítica.

Outras estratégias para não violência são apresentadas por Díaz-Aguado (2015), que nos aponta a aprendizagem cooperativa como uma possibilidade de se praticar valores democráticos, tais como tolerância, igualdade e respeito mútuo. Esses valores caracterizam-se como antítese do bullying e devem ser incorporados como conteúdo de ensino e de aprendizagem. De acordo com a autora, os alunos se beneficiam com a aprendizagem cooperativa, tanto no que diz respeito aos conteúdos, como em relação à educação em valores. Nesses estudos, Díaz-Aguado (2015) mostra também que, para se prevenir o bullying escolar, é necessário que se elimine as situações de exclusão do protagonismo escolar, ou seja, quanto maior for o contato dos sujeitos e a convivência com valores de respeito mútuo, empatia e não violência, maior será a probabilidade de que a prevenção ao bullying seja eficiente.

Os recursos supracitados para uma educação para a paz, embora sejam eficazes no combate à violência, só serão consolidados desde que façam parte da cultura escolar, com o envolvimento da comunidade escolar, com projetos que possam favorecer a autonomia moral dos educandos e um clima escolar favorável a uma convivência mais democrática, na qual prevaleça o respeito, a cooperação, a justiça e a solidariedade.

\section{Objetivos e justificativa}

Este estudo tem como objetivo analisar as percepções de estudantes de uma escola particular de Ensino Fundamental II (EF II) e Ensino Médio 
(EM) sobre o maltrato entre iguais, no que se refere à sua incidência e características. Tem-se também o intuito de oferecer à escola investigada dados prévios de diagnóstico, para que possam ser planejados programas de intervenção voltados para a prevenção e erradicação do bullying no ambiente educativo. Além disso, visa contribuir para a construção de conhecimentos sobre recursos de avaliação que podem ser empregados no ambiente educativo, seja por profissionais da escola, seja por pesquisadores, com o intuito de se identificar esse tipo de violência e conhecer suas peculiaridades e formas de manifestação.

De acordo com Avilés Martínez (2013), a aproximação ao fenômeno do maltrato entre iguais nos diferentes contextos escolares requer um processo de reflexão, informação, formação e planejamento. Portanto deve-se ter como ponto de partida o conhecimento da realidade da comunidade educativa, o que propiciará informações básicas para a construção de iniciativas para que o bullying seja combatido. Desse modo, antes de se iniciar qualquer intervenção, faz-se necessário colocar em ação ferramentas de diagnóstico que possibilitem investigar a qualidade e quantidade do que está ocorrendo na escola, no que se refere ao bullying, para que sejam analisadas as necessidades da comunidade escolar e, então, possam se planejadas intervenções que consigam reduzi-lo: "Portanto, a análise de necessidades precede a qualquer mudança" (AVILÉS MARTÍNEZ, 2013, p. 23).

$\mathrm{O}$ autor explicita ainda que a realidade da comunidade educativa pode ser analisada em duas esferas: a do projeto pedagógico da escola, no que se refere à sua orientação educativa, à importância que se dá à convivência e à qualidade das relações interpessoais; e a da situação em que a escola e a comunidade educativa se encontram, a respeito do tratamento do bullying, quais aspectos da escola já são favoráveis em seu combate e quais vão ao encontro do objetivo de sua erradicação (AVILÉS MARTÍNEZ, 2013).

Múltiplas são as formas para se realizar tais avaliações; focalizaremos neste estudo esse segundo aspecto, em especial aquele que diz respeito à situação que a escola se encontra no que se refere a esse fenômeno, em especial à sua incidência $\mathrm{e}$ características.
Esse tipo de diagnóstico possibilita abordar o bullying como um fenômeno que deve ser reconhecido, analisado e com relação ao qual é necessário um posicionamento moral. A comunidade escolar deve posicionar-se diante dessa realidade, o que facilitará e contribuirá para a adoção de posturas morais aceitáveis no grupo. De acordo com Avilés Martínez (2013), construir um projeto "antibllying" no âmbito da comunidade educativa requer o desenvolvimento de diversas etapas e respostas a diferentes questões, e uma das etapas que mais exige realismo e sinceridade é aquela em que são analisadas as necessidades da comunidade com relação ao bullying.

É imprescindível apreciar a situação própria de cada escola para se compreender suas necessidades sobre a violência e o bullying e, então, construir recursos para sua prevenção e erradicação. Por conseguinte, somente por meio do diagnóstico é possível levantar tais dados e planejar ações, e para que estas sejam projetadas é preciso identificar o que se quer mudar, sobre o que se quer atuar. Do mesmo modo, o diagnóstico também é importante para que sirva de referência para a avaliação das intervenções implantadas na escola, pois fornecem indicadores, e quando sistematizado, é um recurso que permite mensurar o grau com que os objetivos das ações implantadas estão sendo cumpridos, se as estratégias devem ser potencializadas ou modificadas.

Enfim, Avilés Martinez (2013) apresenta diversos pontos que justificam a relevância de se realizar um levantamento de necessidades antes de se dar início a ações interventivas, a saber: leva os membros da comunidade escolar a assumirem de algum modo uma postura diante da violência e do bullying; promove uma sensibilização, reflexão e, até mesmo, conscientização; permite avaliar o quanto de bullying e de que tipo está ocorrendo naquele contexto; possibilita que se conheça em que ponto a escola está com relação a esse fenômeno, a partir do qual deverá partir para intervir; e oferece "um ponto de coesão e de identificação" para a comunidade escolar, sobre o qual será trabalhado algo em comum e que implique a todos.

Nessa direção, esta pesquisa procura responder às perguntas: Quais são os problemas específicos a respeito do bullying entre alunos que a escola parti- 
cipante apresenta? Que tipo de bullying acontece? Em que medida? Onde ocorre? Quem o sofre? O que é feito? As vítimas têm possibilidades de contar o que está acontecendo? Veem possibilidades de mudanças a respeito? Que iniciativas a escola poderia empregar para sua prevenção e erradicação?

Assim, buscamos conhecer, a partir da percepção de alunos, a realidade de uma determinada comunidade educativa sobre o bullying, aspecto essencial para viabilizar a participação dos membros da comunidade escolar no processo de reflexão, formação, decisão e atuação contra esse fenômeno. Também visamos contribuir para a produção de conhecimentos a respeito de formas de diagnóstico que podem ser realizados nesse sentido.

\section{Percurso metodológico}

A pesquisa realizada é de nível exploratório, de abordagem quantiqualitativa e do tipo Estudo de Caso Intrínseco, uma vez que o interesse se voltou para um caso particular (ANDRÉ, 2008; GAMBOA, 2003; GIL, 2012). Buscou-se investigar a avaliação das situações de maus-tratos entre iguais no ambiente escolar, a partir da percepção de alunos de uma escola particular de Educação Básica, mais especificamente em uma das unidades que abrange o Ensino Fundamental (EF II) $-6^{\circ}$ ao $9^{\circ}$ ano - e o Ensino Médio (EM), que possui um total de 574 alunos. Participaram da pesquisa todos aqueles alunos que concordaram de modo voluntário, atingindo-se a amostra de 508 estudantes, o que equivale a $88 \%$ do total de matriculados na escola nos níveis de ensino pesquisados. Este estudo faz parte de um projeto maior, que tem como temática a melhoria da convivência e do clima escolar na escola, tendo sua aprovação pelo Comitê de Ética em Pesquisa da instituição ao qual se vincula (CAE 46505415.8.0000.5406; parecer 1.247.109).

$\mathrm{O}$ instrumento utilizado para avaliar as percepções de alunos foi baseado naquele apresentado por Avilés Martinez (2013, p. 70-73), cujo nome é "Questionário sobre pré-concepções de intimidação e maltrato entre iguais - PRECONCIMEI (Folha de resposta para os alunos)", o qual foi adaptado por Avilés Martinez (2013) com base no elaborado por Ortega, Mora-Merchán e Mora (s/d). Consiste em um questionário que tem como foco o maltrato entre os alunos, objetivando avaliar que tipo de bullying existe na comunidade educativa e de que qualidade é. Tal instrumento é do tipo autoinforme, o que, segundo Avilés Martinez (2013), tem sido um meio bastante empregado pelos estudiosos para se investigar a incidência do bullying na escola. É composto por doze questões, com diferentes alternativas de respostas, que avaliam as seguintes dimensões: as formas de intimidação entre iguais na escola; as situações sobre como e onde se produz o maltrato; as percepções da vítima sobre o maltrato, incluindo frequência e duração; as percepções do agressor; as percepções dos espectadores; e as propostas apresentadas pelos alunos para a solução desse problema.

O questionário foi aplicado no segundo semestre de 2015, em sala de aula, e preenchido individualmente por cada aluno participante. O tempo de aplicação foi de aproximadamente 40 minutos.

Para o tratamento dos resultados foi utilizado o software SPSS $^{\circ}$ Statistics Version 19,0 (IBM, 2010), sendo que os dados foram descritos e analisados por meio de frequência absoluta e frequência relativa, destacando-se que em vários casos os respondentes poderiam assinalar mais de uma alternativa de resposta em uma mesma questão, o que fez com que a soma total das categorias de respostas ultrapassasse $100 \%$. Procurou-se ainda verificar se as percepções dos alunos se associavam ao nível de ensino (EF II ou EM), utilizando-se o Teste Qui-quadrado e, em tabelas 2 x 2, a Prova Exata de Fisher, considerando o nível de significância de 0,05 .

\section{Resultados e discussões}

Responderam ao questionário 508 estudantes: 309 (61\%) do EF II e 199 (39\%) do Ensino Médio. A distribuição dos alunos por ano/série em cada nível de ensino foi de: no EF II, 73 alunos (24\%) do $6^{\circ}$ ano, $72(23 \%)$ do $7^{\circ}$ ano, 80 (26\%) do $8^{\circ}$ ano e $84(27 \%)$ do $9^{\circ}$ ano; e no EM, $81(41 \%)$ na $1^{\mathrm{a}}$ série, $58(29 \%)$ na $2^{\mathrm{a}}$ série e $60(30 \%)$ na $3^{\mathrm{a}}$ série.

Com relação ao gênero, a amostra não apresentou diferenças significativas na distribuição entre meninos e meninas, de modo que no total participaram 260 meninos $(51,2 \%)$ e 248 meninas (48,8\%). No EF II contou-se com 161 meninos 
$(52,1 \%)$ e $148(47,9 \%)$ meninas, e no EM, com 99 meninos $(49,7 \%)$ e 100 meninas $(50,3 \%)$. A média de idade no EF II foi de 12,2 anos; no EM, de 15,6 anos.

$\mathrm{Na}$ sequência apresentaremos os dados colhidos por meio do questionário de percepção sobre o bullying, com o intuito de compararmos as respostas dos alunos do EF II com as dos EM, em que os dados serão apresentados em termos de frequência relativa (porcentagem). Para cada categoria investigada, as diferenças que apresentarem significância na Prova Exata de Fisher, para p $<0,05$, serão sinalizadas com a legenda "(SIG)". No caso do Teste Qui-quadrado, seu valor e significância serão apontados no próprio texto.

No Gráfico 1, podem ser observadas as respostas referentes à dimensão Formas de intimidação entre iguais.

Gráfico 1 - Quais são, na sua opinião, as formas mais frequentes de maltrato entre colegas?

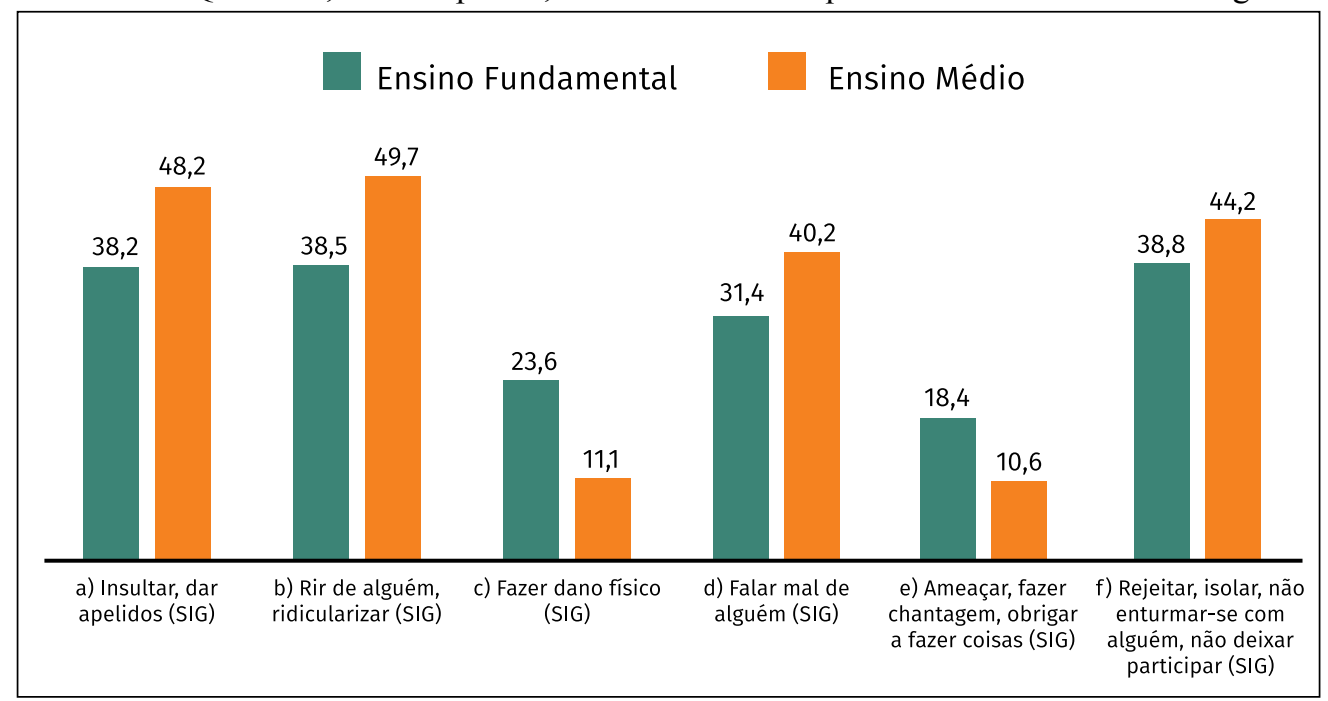

Fonte: Elaborado pelos autores com os dados da pesquisa.

Tal como pode ser visualizado no Gráfico 1, as formas mais frequentes de maltrato apontadas pelos estudantes, tanto do EM como do EF II, foram: "rir de alguém, ridicularizar", "insultar, dar apelidos", "rejeitar, isolar, não se enturmar com alguém, não deixar participar" e "falar mal de alguém", sendo que, em todas essas categorias de maus-tratos, o EM demonstrou maior ocorrência do que o EF II, e na maioria delas de modo significante. Compareceram, ainda, apesar de em menor frequência, as situações de "fazer dano físico" e "ameaçar, fazer chantagem, obrigar a fazer as coisas", em que os alunos do EF II apontaram de modo mais significante esses fatos do que os estudantes do EM.

Observa-se que esses resultados apontam uma relativa diferença entre os pré-adolescentes e adolescentes nas manifestações das formas de maus-tratos, com predominância verbal para os últimos e danos físicos para os primeiros. Segundo Oliveira (2012), estudiosos indicam que, com o passar dos anos e com o surgimento de habilidades verbais e de uma maior autorregulação por parte da criança, há uma redução das agressões físicas e aumento das agressões verbais, apresentando-se, então, mudanças nas formas de agressão nas relações interindividuais. Esse tipo de manifestação vai ao encontro do apresentado por Marques (2015) no referente às estratégias de resolução de conflitos utilizadas por crianças, pré-adolescentes e adolescentes, em que é possível visualizar padrões que se diferenciam ao longo do desenvolvimento. Na criança são encontradas estratégias físicas e impulsivas, as quais são menos elaboradas por evidenciarem uma maior dificuldade no controle dos impulsos, assim como de verbalização de ideias e sentimentos e de se colocar na perspectiva do outro. Nos indivíduos mais velhos há uma diminuição da impulsividade e os desejos podem ser demonstrados de modo verbal e não mais fisicamente. Contudo, nessas situações de maus-tratos, mesmo que seja de modo mais so- 
cial, verbal e menos confrontativo, ainda pode ser identificada a dificuldade de se colocar no lugar do outro, empaticamente falando, uma vez que expressa o desrespeito pelos sentimentos, pensamentos e direitos alheios, fazendo-se necessários, também, os cuidados e atenção para tais casos.

Com relação à dimensão Situações sobre como e onde se produz o maltrato, no Gráfico 2 são apresentados os locais em que essas têm maior ocorrência, segundo os alunos.

Gráfico 2 - Em que lugares costumam acontecer essas situações de intimidação?

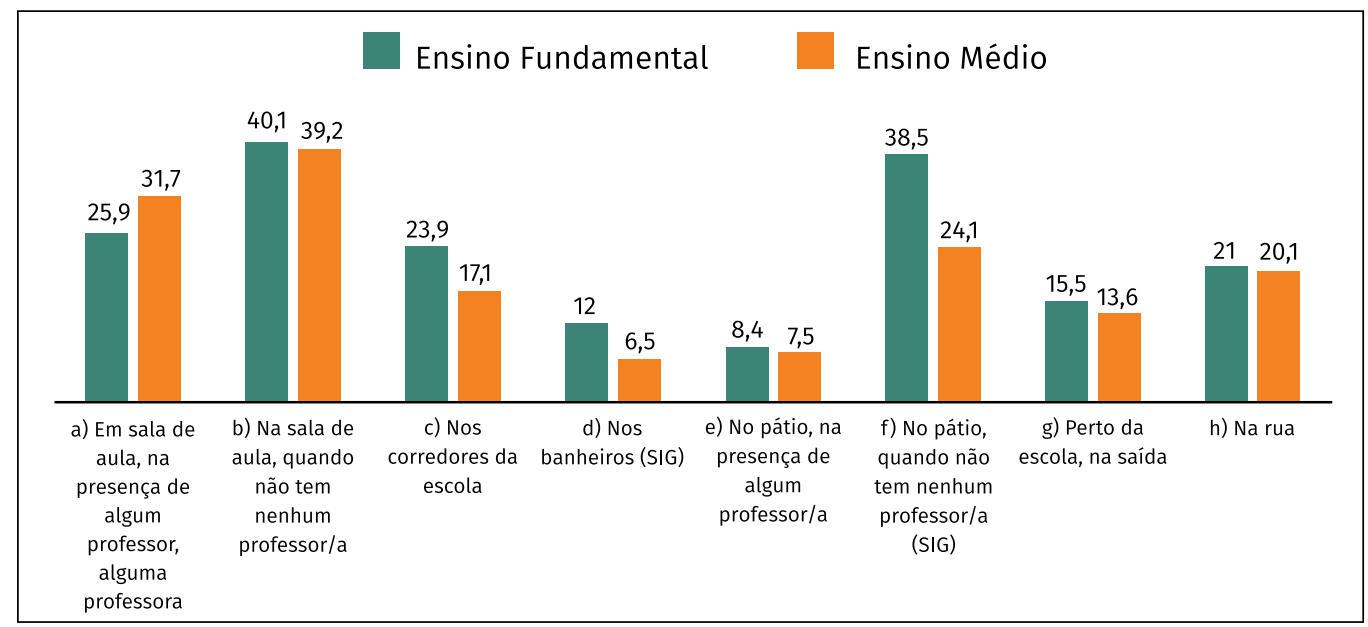

Fonte: Elaborado pelos autores com os dados da pesquisa.

De acordo com os dados apresentados no Gráfico 2, os locais nos quais mais ocorrem as situações de intimidação, tanto no EF II como no EM, são: "na sala de aula, quando não tem nenhum professor", "no pátio, quando não tem nenhum professor" e "em sala de aula, na presença de algum professor". Observa-se, porém, que "no pátio, quando não tem nenhum professor", a ocorrência foi maior e estatisticamente significante no EF II. Outros lugares também citados, em seguida, nos dois níveis de ensino, foram: "nos corredores da escola", "na rua" e "perto da escola, na saída". E em menor frequência: "nos banheiros" (com maior indicação, e com diferença estatisticamente significante, no EF II) e "no pátio, na presença de algum professor".

Ainda nessa dimensão, questionou-se acerca de quem da escola costumava parar as situações de maltrato. No Gráfico 3 podem ser visualizadas as respostas a tal pergunta.

Gráfico 3 - Quem costuma parar as situações de intimidação?

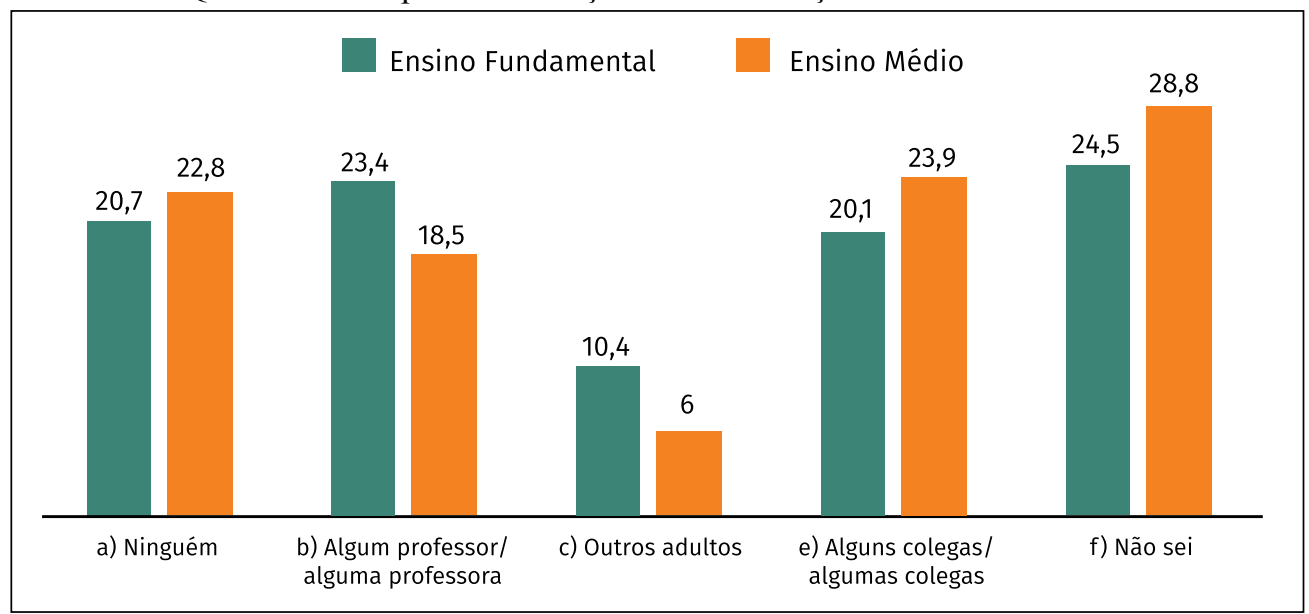

Fonte: Elaborado pelos autores com os dados da pesquisa. 
O que podemos verificar, com base no Gráfico 3 , é que comparecem, com frequências próximas, as categorias: "não sei", "ninguém", "algum professor/alguma professora", "alguns colegas/algumas colegas" e, em menor frequência, "outros adultos". Apesar de não serem encontradas diferenças significantes entre os dois níveis de ensino, há uma tendência maior de os alunos do EM não receberem auxílio dos adultos para resolverem essas situações. Mesmo assim, tanto no EF II como no EM, se juntarmos as categorias "não sei" e "ninguém", vemos que há pouca interferência dos adultos nessas situações, assim como dos próprios colegas, apesar de no EM haver uma tendência maior de os amigos procurarem cessá-las.

Durante a convivência escolar, o conflito pode ser resultante das relações humanas como meio de desenvolvimento; por outro lado, parece que essas situações de maus-tratos acontecem inclusive em presença de adultos, de professores dando aula. Avilés Martinez (2013) ressalta a importância de que o professor exerça a observação do que acontece no grupo, diferenciando: situações que podem ser provocadas pela desmotivação e apatia dos alunos ligadas à prática educativa do docente; situações de confronto às normas e à autoridade docente; incidentes decorrentes de falta de normas e de respeito, situações de conflitos, ausência ou falta de regulação de hábitos e costumes na convivência do grupo. O autor ressalta ainda os incidentes de gozação, ridicularização, agressão física ou verbal, ameaças, dentre outros, que denotam foco repetido contra uma pessoa ou algum traço físico pertencente a esta e que possam caracterizar maltrato contínuo ou bullying. Com esses resultados ainda não é possível afirmar que as situações percebidas e relatadas pelos participantes configuram bullying, pois ainda não temos dados suficientes para afirmar que contemplam aquelas características presentes nesse tipo de conduta (ser entre pares; ter a intencionalidade de ferir o alvo; ser recorrente; e contar com a presença de espectadores/pares), porém, com os resultados adiante, podemos visualizar sua aproximação com esses aspectos.

Nessa direção, primeiro apresentaremos os dados das três seguintes dimensões: as percepções da vítima sobre o maltrato, incluindo frequência e duração; as percepções do agressor; e as percepções dos espectadores, para depois discuti-los em conjunto.

Assim, a próxima dimensão avaliada foi a relativa à vitimização, uma vez que aborda a Percepção da vítima com relação aos maus tratos. No Gráfico 4 apresentamos o primeiro aspecto investigado, concernente à frequência com a qual o respondente sentiu-se intimidado por colegas de sua sala.

Gráfico 4 - Quantas vezes, nessa turma, você foi intimidado ou maltratado por alguém ou alguns de seus colegas?

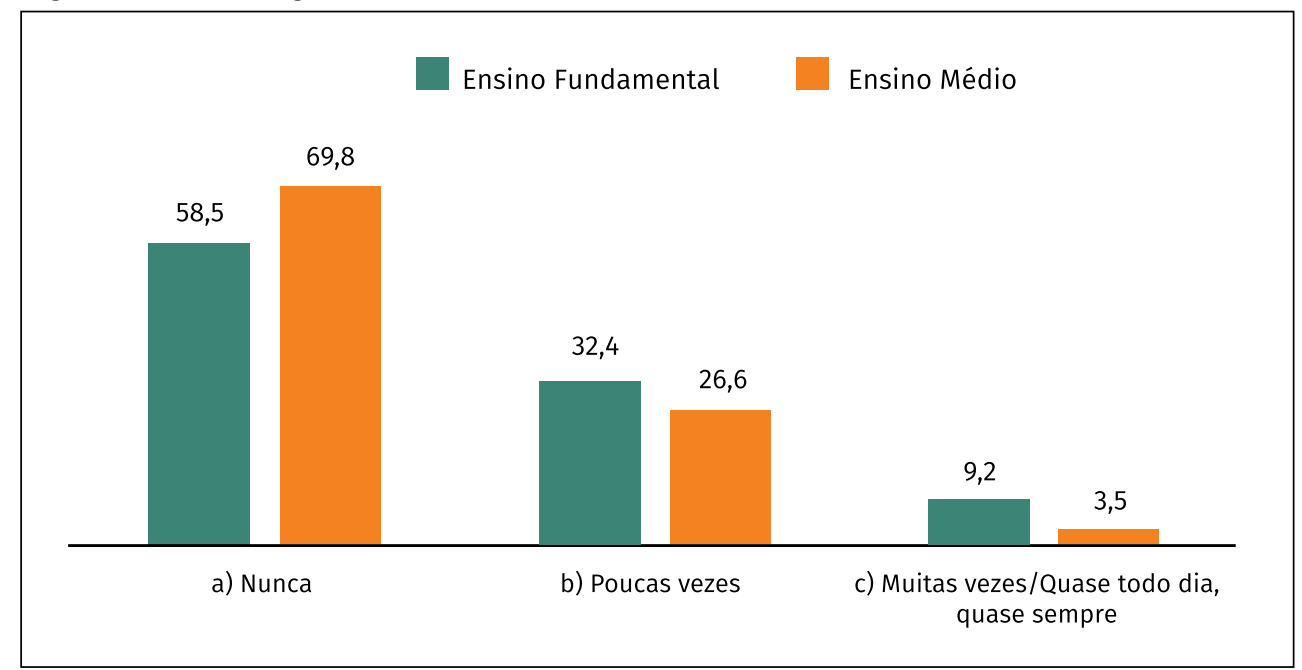

Fonte: Elaborado pelos autores com os dados da pesquisa. 
Por meio do Gráfico 4 é possível identificar que a maioria dos alunos relata que "nunca" foi intimidada por colegas da turma, sendo decrescente a frequência com a qual os alunos apontam a ocorrência desse tipo de situação, apresentando como segunda maior indicação a categoria "poucas vezes", depois "muitas vezes/ quase todo dia, quase sempre". Assim, observa-se que são menos frequentes as situações em que os alunos tenham se sentido intimidados "muitas vezes/quase todo dia, quase sempre". Por outro lado, constata-se que ainda há esses casos, os quais são mais frequentes no EF II do que no EM, ao passo que a indicação de que a situação de maltrato "nunca" aconteceu com o respondente é mais frequente no EM. Destaca-se que tais diferenças foram estatisticamente significantes $(\mathrm{X} 2=11,50 ; \mathrm{p}<0,05)$.

Em seguida foi perguntado se no caso de terem sido intimidados alguma vez por algum colega, desde quando isso ocorria. A maioria dos alunos assinalou a categoria "ninguém me intimidou, nunca" (67,6\% no EF II e 80,9\% no EM). Com bem menor frequência comparecem as demais categorias, na seguinte ordem decrescente: "há pouco tempo, há algumas semanas" (14,2\% no EF II e $6 \%$ no EM), "desde pequenos" (7,1\% no EF II e 6\% no EM), "desde sempre" (6,5\% no EF II e 2,5\% no EM) e "durante todo o curso" (1,9\% no EF II e $2 \%$ no EM). Observa-se que na primeira categoria, "ninguém me intimidou, nunca", a frequência é maior entre os alunos de EM, ao passo que nas demais, com exceção da categoria "durante todo o curso", a maior frequência aparece entre os alunos de EF II, sendo as diferenças estatisticamente significantes $(\mathrm{X} 2=$ $14,40 ; \mathrm{p}<0,05)$.

Ainda nessa dimensão, os respondentes foram indagados se, no caso de se sentirem intimidados, recorriam a alguém para falar a respeito (Gráfico 5).

Gráfico 5 - Se alguém lhe intimida, você fala com alguém a respeito do que está acontecendo?

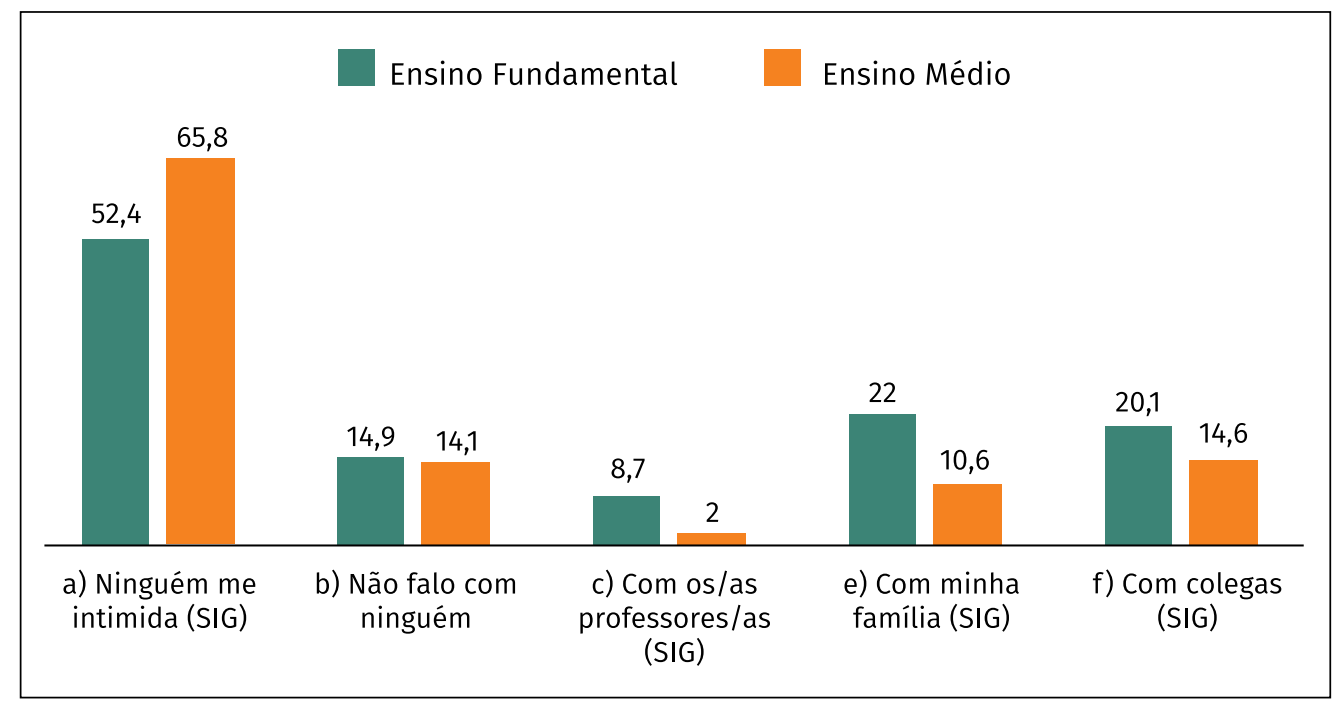

Fonte: Elaborado pelos autores com os dados da pesquisa.

Tal como pode ser observado no Gráfico 5, a maioria dos alunos assinalou a categoria "ninguém me intimida", sendo maior e estatisticamente significante a indicação entre os alunos do EM. Por outro lado, compareceram também as demais categorias, que revelaram que, no caso de se sentirem intimidados, os alunos contam o ocorrido à família e aos colegas, ou não falam com ninguém, sendo que a escolha de contar ao professor acontece em último caso. Verifica-se, ainda, que os alunos do EF II recorrem mais ao compartilhamento dessas situações com outras pessoas do que os de EM.

No Gráfico 6 são apresentados os dados de percepção dos alunos com relação aos motivos pelos quais poderiam ter sido intimidados. 
Gráfico 6 - Se você foi intimidado alguma vez, qual você acha que foi o motivo?

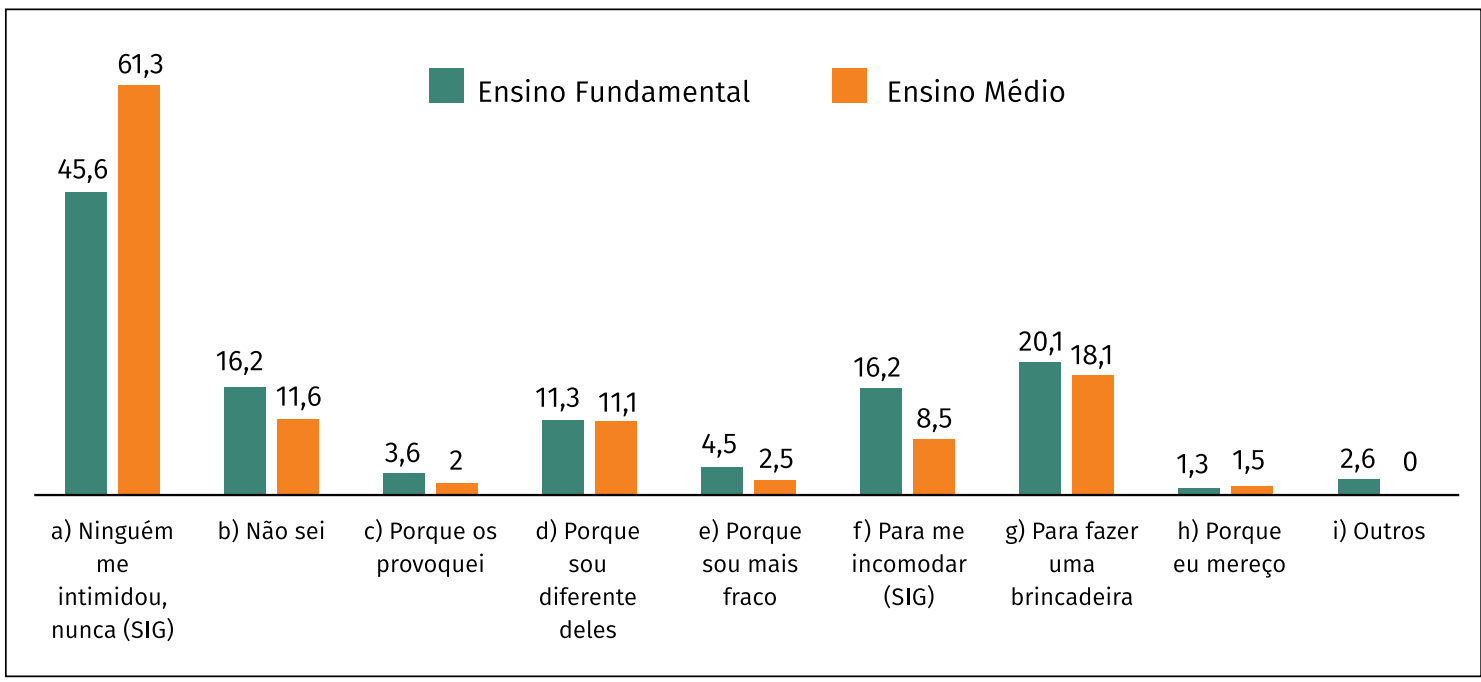

Fonte: Elaborado pelos autores com os dados da pesquisa.

Novamente a maior frequência se deu na categoria "ninguém me intimidou, nunca", com mais ocorrência no EM e de modo estatisticamente significante. Em seguida, foi assinalada nos dois níveis de ensino a resposta "para fazer uma brincadeira". A categoria "não sei" aparece logo após. No EF II vem a seguir "para me incomodar" e em menor número no EM, com diferença significante. A categoria "porque sou diferente" também aparece de modo considerável, e depois, em menor número, as respostas "porque os provoquei", "porque sou mais fraco" e "porque eu mereço". Alguns alunos do EF II apontaram outros motivos, especificando-os: por causa do meu peso; porque sou gay; pela minha religião; para me envergonhar.

Com relação à dimensão Percepção do agres- sor, o primeiro aspecto investigado foi se o respondente intimidava ou maltratava algum colega. A maioria declarou, em ambos os níveis de ensino, nunca ter mexido com alguém $(58,6 \%$ no EF II e $64,8 \%$ no EM). Todavia foi considerável a quantidade de indivíduos que assinalou intimidar ou maltratar um colega algumas vezes $(36,12 \%$ no EF II e $28,1 \%$ no EM), sendo bem menor o número de respostas nas alternativas "com certa frequência" e "quase todo o dia" (cerca de 3\% no EF II e no EM). Ressalta-se que não houve variação estatisticamente significante entre as respostas do EF II e do EM.

Em seguida, tal como apresentado no Gráfico 7, foi perguntado os motivos pelos quais o respondente já havia participado de alguma situação de intimidação, caso isso tivesse acontecido.

Gráfico 7 - Se você participou de situações de intimidação contra algum colega ou colegas, por que fez isso?

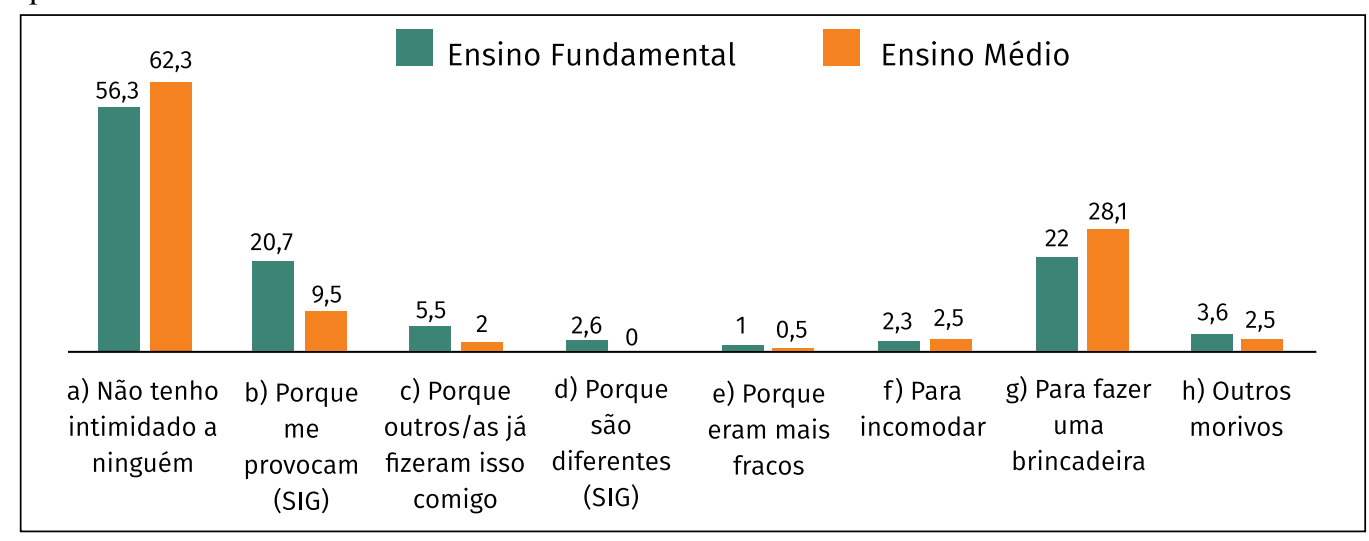

Fonte: Elaborado pelos autores com os dados da pesquisa. 
Observamos, com base no Gráfico 7, que novamente a maioria dos alunos de ambos os níveis de ensino declarou nunca ter participado de situações de intimidação contra algum colega ou colegas. Por outro lado, também foi considerável o número de pessoas que relatou ter feito parte desse tipo de ocorrência, sendo o principal motivo levantado "para fazer uma brincadeira" e, em seguida, "porque me provocam", sendo que nesta categoria foi estatisticamente significante maior o número de respondentes do EF II. Em menor número foram assinaladas as alternativas: "porque já fizeram isso comigo", "porque são diferentes", "para incomodar", "porque eram mais fracos" e "outros motivos".

A próxima dimensão pesquisada foi a Percepção dos espectadores, em que se perguntou, primeiramente, qual era, na opinião do respondente, o motivo pelo qual alguns colegas intimidavam a outros (Gráfico 8).

Gráfico 8 - Para você, por que alguns/algumas colegas intimidam os(as) outros(as)?

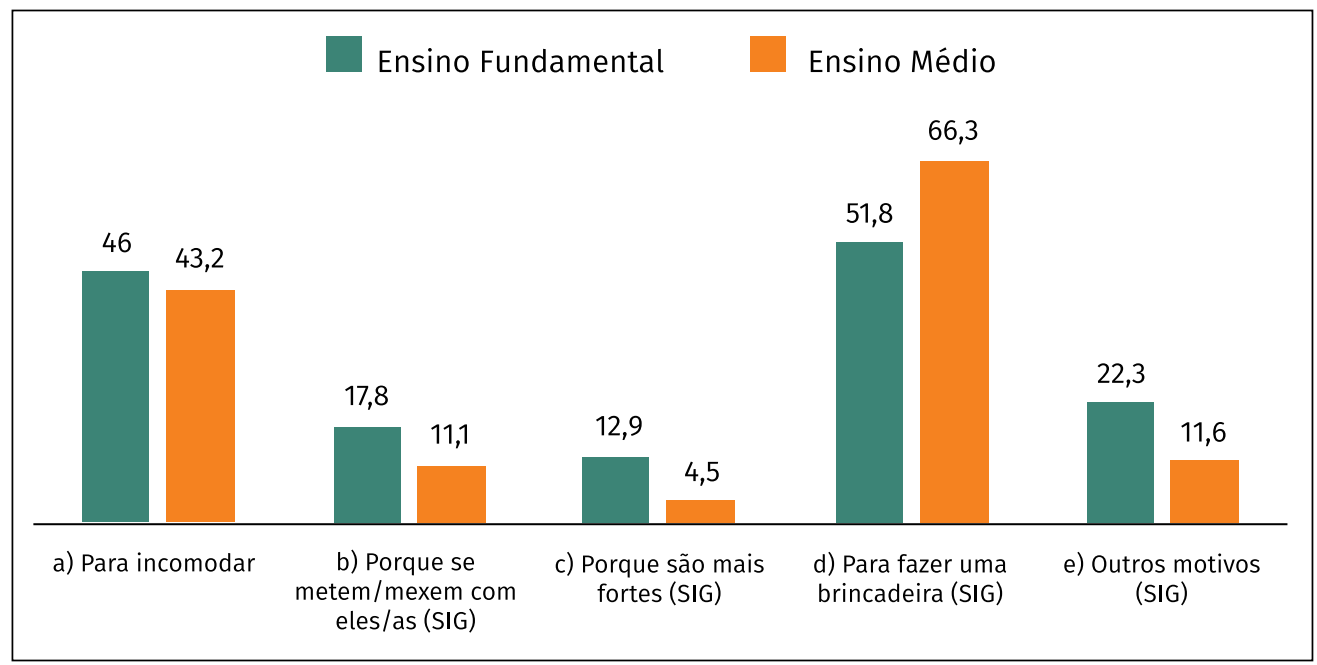

Fonte: Elaborado pelos autores com os dados da pesquisa.

Verificamos no Gráfico 8 que a resposta com maior frequência nos dois níveis de ensino foi "para fazer uma brincadeira", com mais respostas e de modo estatisticamente significante pelos alunos de EM. Em seguida, também em ambos os níveis de ensino, compareceu a resposta "para incomodar". Outros motivos assinalados foram: "porque se metem/ mexem com eles/as", "porque são mais fortes" e "outros motivos"; em todos esses casos houve um maior número de respostas, estatisticamente significante, por parte dos alunos do EF II.

No Gráfico 9 são apresentados os dados relativos à frequência com que os respondentes percebem que têm ocorrido situações de intimidação na escola durante o último trimestre, tais como dar apelidos, ridicularizar, bater, chutar, empurrar, ameaçar, rejeitar, não se juntar etc.

As respostas não apresentaram variações importantes quando comparados os dois níveis de ensino, sendo que, em ordem das maiores para as menores frequências, as alternativas assinaladas foram: "menos de cinco vezes", "nunca", "todos os dias", "entre cinco e dez vezes", "entre dez e vinte vezes" e "mais de vinte vezes".

Com base nos dados apresentados relativos à percepção das vítimas, agressores e telespectadores, podemos indicar que, apesar de a maioria dos estudantes relatar nunca ter sofrido ou nunca ter sido o agente de algum tipo de intimidação e maltrato, ainda é considerável o número daqueles que passaram e ainda passam por esse tipo de situação como alvo, e/ou realizaram esse tipo de ação como agente, ou ainda fazem parte disso como telespectadores. Chama atenção ainda o fato de que ao serem questionados sobre a frequência com que os respondentes percebem que têm ocorrido situações de intimidação na escola durante o último trimestre (tais como dar apelidos, ridicularizar, bater, chutar, 
empurrar, ameaçar, rejeitar, não se juntar etc.), a categoria nunca aparecer em menor frequência que as demais, as quais se referem à ocorrência desse tipo de situação de "menos de cinco vezes" por semana até "todos os dias", sendo que esta última aparece em quase $20 \%$ das respostas.

Gráfico 9 - Com qual frequência têm acontecido intimidações na sua escola durante o trimestre?

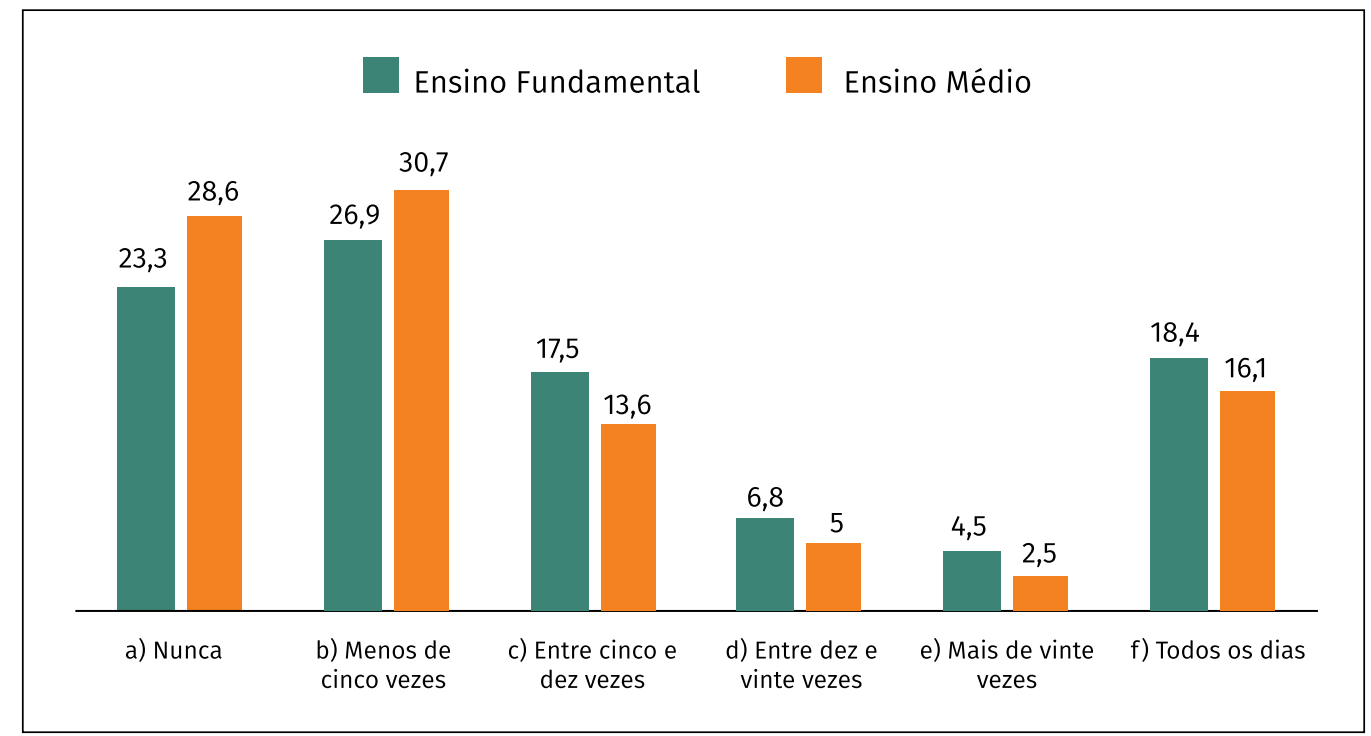

Fonte: Elaborado pelos autores com os dados da pesquisa.

Esses dados confirmam o que estudiosos (AVILÉS MARTÍNEZ, 2013; DÍAZ-AGUADO, 2015) afirmam, de que há, sim, situações de maus-tratos na escola, e que estas se configuram na presença e até mesmo na estabilização dos papéis de vítimas, agressores e testemunhas, sendo que essa estabilização ocorre nos casos em que as situações perduram por mais tempo e não há esforços para modificá-las. Segundo Diáz-Aguado (2006, 2015), é possível situar o bullying como um fenômeno que faz parte habitual da cultura escolar tradicional, uma vez que ao longo da vida escolar todos os alunos parecem ter contato com esse fenômeno em diferentes papéis, seja no de vítima, de agressor ou de espectador.

A autora ressalta que a sociedade tem tomado consciência da presença do fenômeno do bullying escolar, e que este é um problema tão antigo como a própria escola tradicional, que reproduz um modelo de relação de dominação-submissão, e que representa a antítese do que se quer ser e dos valores que almejamos: a igualdade, o respeito mútuo, a tolerância e a paz. Como consequência às pessoas que com ele convivem, Díaz-Aguado
(2006) aponta que o bullying escolar: com relação à vítima, produz medo e rejeição ao contexto no qual a violência ocorre, perda de confiança, além de outras dificuldades, como problemas de rendimento, baixa autoestima; no agressor, podem aumentar os problemas que o levaram a abusar de sua força, diminuindo sua capacidade de compreensão moral e empatia, de modo a identificar-se com um estilo violento de interação, o que representa um problema ao seu desenvolvimento e ao estabelecimento de relações positivas; nas pessoas que não têm uma participação direta na violência, mas convivem com ela sem fazer nada para evitá-la, pode produzir problemas semelhantes, mesmo que em menor grau, aos apresentados tanto pela vítima (receio de poder vir ser a vítima), como pelo agressor (redução da empatia), contribuindo para aumentar a falta de sensibilidade aos problemas alheios, o que pode incorrer no risco de que sejam os próximos protagonistas da violência.

Assim, mesmo que na apresentação dos dados da presente pesquisa a maioria declare que esse tipo de situação não acontece ou nunca aconte- 
ceu, é muito importante considerar os casos que apontam, sim, para a sua presença, que por sinal não são poucos, e nem tão pontuais, como pôde ser visualizado em números e pelos gráficos supracitados. Um ponto importante a destacar são as diferenças de percepções quando os sujeitos se colocam na situação de vítimas e na de agressores, sobretudo no EF II, em que os estudantes se reconheceram mais como vítimas do que como agressores. Ou seja, reconhecem e/ou são mais sensíveis à agressão contra si do que em relação a outrem, especialmente quando se está no papel de agente.

Outro aspecto relevante é quando são questionados sobre os motivos pelos quais os próprios respondentes já haviam participado de alguma situação de intimidação, caso isso tivesse acontecido. Apesar de também a maioria ter declarado nunca ter feito esse tipo de coisa, chama atenção o número daqueles que responderam que no caso de o terem feito foi por brincadeira. Não obstante, quando comparamos essa percepção (que é a do agressor) com a da vítima, constata-se que, quando no papel de vítima, os respondentes percebem menos essa situação como uma brincadeira, talvez porque nesse lugar (o de vítima) consigam ser mais sensíveis à dor que esse tipo de brincadeira (o qual muitas vezes não é uma brincadeira, mas uma manifestação de violência) gera. Quando nos dirigimos para a percepção dos respondentes no papel de telespectador, e perguntamos qual era, na opinião do respondente, o motivo pelo qual alguns colegas intimidavam a outros, a brincadeira também comparece, e agora como o principal tipo de resposta em ambos os níveis de ensino, apesar de os alunos do EM justificarem mais dessa forma.

De modo geral, os alunos do EF II justificam mais o maltrato a partir do comportamento do outro (do que os do EM): porque provocam, porque mexem com ele, porque são mais fortes (pelo fato de o desequilíbrio de poder ser maior). Sobre esse último dado, Díaz-Aguado (2006) destaca que há uma tendência, por parte dos agressores e de pessoas no entorno, em se responsabilizar as vítimas de bullying escolar, assim como em outros tipos de violência, desenvolvendo-se um sentimento de cul- pabilidade e justificando, direta ou indiretamente, a ação do agente da agressão.

Outro dado que deve ser discutido é sobre a quem os respondentes, quando se sentem vitimizados, recorrem para pedir ajuda e/ou falar a respeito. Observa-se que os alunos recorrem mais à família e aos colegas, vários não falam nada a ninguém e, por último, recorrem aos professores. Chama atenção o fato de haver aqueles, em maior número, que preferem não falar nada a ninguém do que recorrer aos professores.

Esses dados vão ao encontro daqueles encontrados por Díaz-Aguado (2006, 2015), que apontam para uma tendência à passividade diante da violência entre iguais, a qual é detectada na escola tradicional e parece ainda não ter sido superada e se produz mais por falta de recursos do professorado para resolvê-la com eficácia do que por falta de interesse. É importante considerar também que as figuras mais disponíveis para pedir ajuda são os amigos, seguidos pelos familiares. Resultados semelhantes aos observados em outros estudos citados pela autora, nos quais também se destaca a baixa tendência a pedir ajuda ao professorado. Essas diferenças parecem estar estreitamente relacionadas com as que se observam na qualidade da relação que estabelecem com cada figura, do qual se deriva a necessidade de melhorar a relação que os alunos, sobretudo os adolescentes, estabelecem com o professorado para aumentar a tendência a pedir ajuda quando são vítimas da violência ou conhecem colegas que a sofrem. Convém considerar, ainda, a relação com a forma tradicional de definir o papel do professorado, orientado predominantemente a transmitir uma matéria específica dentro do horário previsto para a mesma, e segundo o qual o que acontece fora desse tempo e espaço não é responsabilidade sua. Tendências que podem mudar quando é proporcionada ao professorado uma formação adequada para prevenir a violência e melhorar as relações na escola.

A última dimensão abordada foi Propostas de saída, em que se perguntou aos participantes o que teria que acontecer para que o problema do maltrato fosse resolvido. No Gráfico 10 são apresentados os resultados. 
Gráfico 10 - O que teria que acontecer para que se solucionasse esse problema?

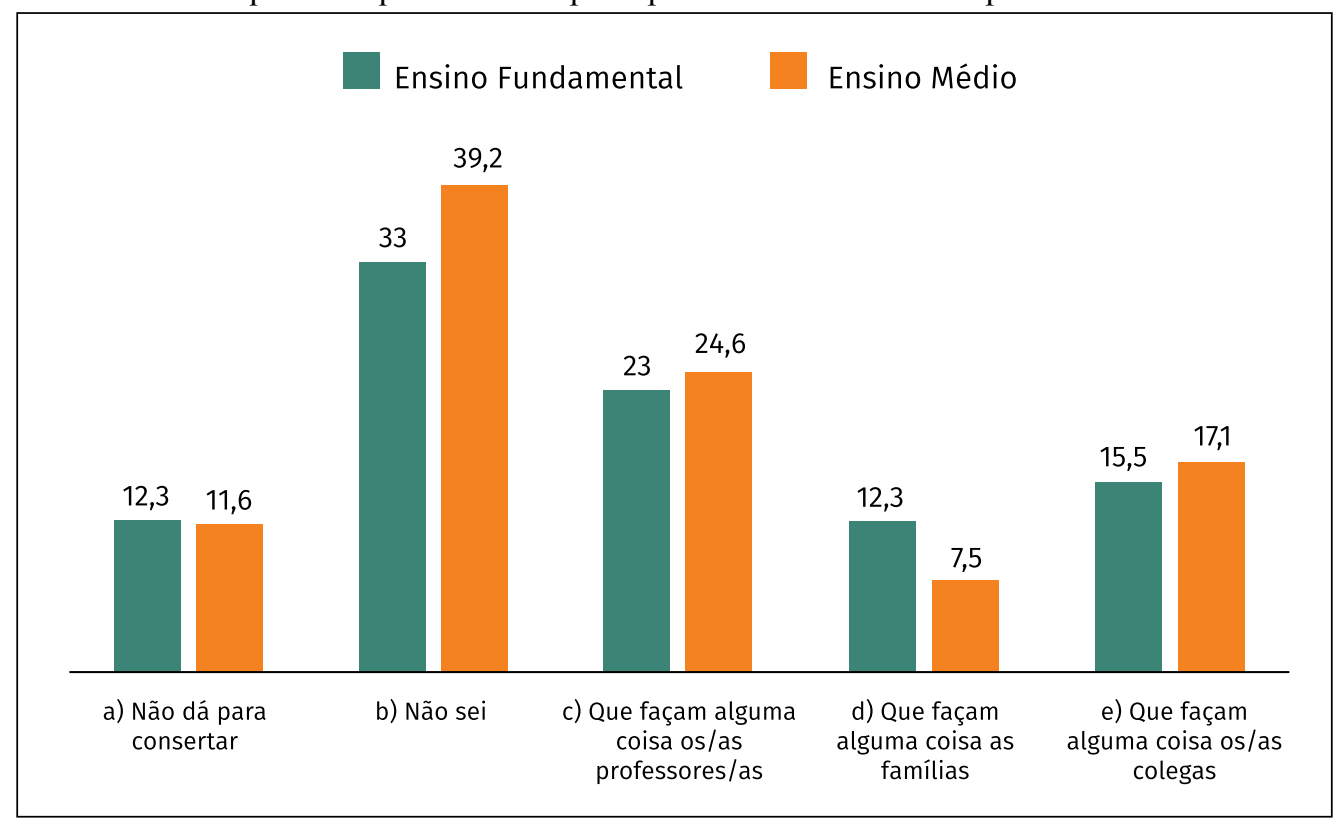

Fonte: Elaborado pelos autores com os dados da pesquisa.

Também não foram encontradas variações significantes quando comparadas as respostas dos participantes do EF II e do EM. Tal como é possível visualizar no Gráfico 10, observa-se que a categoria com maior frequência é "não sei". Em seguida, os alunos apontam os professores como aqueles que devam fazer alguma coisa, depois os colegas e, enfim, as famílias. Há ainda, mesmo que em menor número, aqueles que manifestam que "não dá para consertar".

Nesta dimensão as propostas de saída apontam primeiramente para os professores, ao passo que no Gráfico 5 observa-se que, no caso de se sentirem intimidados, os alunos recorrem à família e aos colegas ou não falam com ninguém, sendo que a escolha de contar ao professor acontece em último caso. Entretanto, quando questionados acerca de quem deveria iniciar um trabalho de prevenção e contenção às situações de bullying, apontam para a figura do professor, o que evidencia que os alunos gostariam de poder ter a ajuda dos adultos da escola, sobretudo do professor, nas situações de intimidação.

Tal como já abordado neste texto, reiteramos a afirmação de Fante e Pedra (2008) que a prevenção do bullying começa pelo conhecimento. A escola precisa reconhecer a existência do fenômeno, destarte, esteja consciente de seus prejuízos para a personalidade e desenvolvimento socioeducacional dos estudantes. Também é necessário instrumentalizar seus profissionais para observação, identificação, diagnóstico, intervenção e encaminhamentos assertivos, conduzindo o tema à discussão com a comunidade escolar, traçando estratégias preventivas capazes de fazer frente ao fenômeno, e incentivando o engajamento de todos.

\section{Considerações finais}

Face ao que ficou exposto neste trabalho, esperamos ter respondido as perguntas iniciais, buscando-se conhecer, a partir da percepção de alunos, a realidade de uma determinada comunidade educativa sobre o bullying, aspecto essencial para viabilizar a participação dos membros da comunidade escolar quanto ao processo de reflexão, formação, decisão e atuação contra esse fenômeno. Também visamos contribuir para a produção de conhecimentos a respeito de formas de diagnóstico que podem ser realizados nesse sentido, apontando possibilidades de intervenções que a escola poderá fomentar com a prática de valores que contemplem a cooperação, a solidariedade, o respeito mútuo, a justiça, proporcionando um 
ambiente democrático e o exercício de uma vida social na própria escola que favoreça a autonomia moral e a liberdade de pensamento.

Compartilhamos com Avilés Martínez (20013) que, para que uma instituição educativa se prepare no combate ao bullying, é essencial que os profissionais da escola tenham informações sobre o que acontece nesse ambiente e acerca do que é esse fenômeno, sendo necessário formação nesse sentido. Todavia, para se aproximar do que acontece entre os grupos de iguais, naquele contexto, é fundamental que seja realizada uma avaliação a respeito, para que se saiba a quantidade e os tipos de bullying que ocorrem naquela escola. O diagnóstico, ao ser levantado, permite a formulação de ferramentas de prevenção que, em suma, coloquem em evidência o protagonismo do jovem no seio da escola. A forma como esta ação transcorrerá deverá levar em conta aspectos da faixa etária do aluno que, com posicionamentos e estratégias distintas, tratarão da compreensão, da análise e do debate que tenham bases morais para resolução dos conflitos que emergem da convivência entre pares. Considerando-se que o bullying deve ser tratado como conteúdo educativo e curricular, com sistematização e intencionalidade, por meio de um projeto "antibullying" inserido em um contexto de Educação em Valores, não há receitas, uma vez que deve ser adaptado a cada realidade e contexto. Não é um problema isolado de um ou outro aluno, que seja o alvo ou o agente de bullying, mas sim de todo o grupo, de toda a comunidade educativa, uma vez que aquele contexto está promovendo, de algum modo, esse tipo de relação.

\section{REFERÊNCIAS}

ABERASTURY, A. Adolescência. Porto Alegre: Artes Médicas, 1980.

ABRAMOVAY, M. Debate: violência, mediação e convivência na escola. In: (Org.). Debate: violência, mediação e convivência na escola. Brasília, DF: Ministério da Educação/TV Escola, 2005. p. 3-10.

ANDRÉ, M. E. D. A. de. Estudo de caso em pesquisa e avaliação educacional. 3. ed. Brasília, DF: Líber Livro, 2008. AQUINO, J. G. Confrontos na sala de aula: uma leitura institucional da relação professor-aluno. São Paulo: Summus, 1996.

AVILÉS MARTINEZ, J. M. Bullying: guia para educadores. Campinas, SP: Mercado de Letras, 2013.

BRASIL. Lei $\mathbf{n}^{\mathbf{0}} \mathbf{1 3 . 1 8 5}$, de 06 de novembro de 2015. Brasília, DF, 2015. Disponível em: <http://www.planalto. gov.br/ccivil_03/_Ato2015-2018/2015/Lei/L13185.htm>. Acesso em: 14 fev. 2016.

CANO, I. Violências nas escolas: uma forma de exclusão social. In: ABRAMOVAY, M. (Org.). Debate: violência, mediação e convivência na escola. Brasília, DF, Ministério da Educação/TV Escola, 2005. p. 11-15.

CHARLOT, B. Relação com o saber, formação dos professores e globalização: questões para a educação hoje. Porto Alegre: Artmed, 2005.

COSTA, R. F. S.; LIMA, R. de C. P. Representações sociais de professores do ensino fundamental sobre violência na escola. In: FREIRE, N. M. B. (Org.). Educação para a tolerância: fundamentos teóricos e prática educacional. Campinas, SP: Mercado de Letras, 2011.p. 171-187.

DEBARBIEUX, E. Violência nas escolas e políticas públicas. In: DEBARBIEUX, E.; BLAYA, C. (Org.). Violência nas escolas: divergências sobre palavras e um desafio político. Brasília, DF: UNESCO, 2002. p. 59-92.

DÍAZ-AGUADO, M. J. Del acoso escolar a la cooperación en las aulas. Madrid, España: Pearson Educación, 2006. Da violência escolar à cooperação na sala de aula. Americana, SP: Adonis, 2015.

FANTE, C. Fenômeno bullying: como prevenir a violência nas escolas e educar para a paz. Campinas, SP: Verus, 2005.

FANTE, C.; PEDRA, J. A. Bullying escolar: perguntas \& respostas. Porto Alegre: Artmed, 2008.

FERNÁNDEZ, I. Prevenção da violência e solução de conflitos: o clima escolar como fator de qualidade. São Paulo: Madras, 2005. 
FOUCAULT, M. A sociedade punitiva. Rio de Janeiro: Zahar, 1997.

GAMBOA, S. S. Pesquisa qualitativa: superando tecnicismos e falsos dualismos. Contrapontos, v. 3, n. 3, p. 393 405, set./dez. 2003.

GIL, A. C. Métodos e técnicas de pesquisa social. 6. ed. São Paulo: Atlas, 2012.

IBM. SPSSC Statistics. Version 19.0. [S.1.]: IBM Company, 2010. 1 CD-ROM.

MARQUES, C. de A. E. Conflitos entre alunos de 11 e 12 anos: causas, estratégias e finalizações. 2015. $237 \mathrm{f}$. Tese (Doutorado em Educação) - Faculdade de Educação da Universidade Estadual de Campinas (UNICAMP), Campinas, SP, 2015.

OLIVEIRA, F. C. Relações entre desenvolvimento moral, percepção da manifestação de condutas agressivas e estilos de resoluções de conflitos em crianças e adolescentes. 2012. 149 f. Dissertação (Mestrado em Educação) - Faculdade de Filosofia e Ciências da Universidade Estadual Paulista (UNESP), Marília, SP, 2012.

PIAGET, J. Os procedimentos da educação moral. In: PARRAT, S.; TRYPHON, A. (Org.). Jean Piaget: sobre a pedagogia. São Paulo: Casa do Psicólogo, 1998. p. 25-58.

. A educação da liberdade. In: ASSIS, O. Z. M. de. (Org.). Construtivismo piagetiano para a catequese com crianças e adolescentes. Campinas, SP: Diretório Nacional de Catequese, [2002]. p. 121-126.

PUIG, J. M. Práticas morais: uma abordagem sociocultural da educação moral. São Paulo: Moderna, 2004.

RUOTTI, C.; ALVES, R.; CUBAS, V. de O. Violência na escola: um guia para pais e professores. São Paulo: Andhep, 2006.

SINDICATO DOS PROFESSORES DO ENSINO OFICIAL DO ESTADO DE SÃO PAULO. Violência nas escolas: o olhar dos professores. São Paulo, 2013. Disponível em: <http://www.apeoesp.org.br/d/sistema/publicacoes/.../ violencia-apeoesp-web.pdf>. Acesso em: 09 fev. 2013.

TOGNETTA, L. R. P. Educação dos sentimentos: um caminho para a paz. In: ASSIS, O. Z. M. de. (Org.). Construtivismo piagetiano para catequese com crianças e adolescentes. Campinas, SP: Diretório Nacional de Catequese, [2002]. p. 109-120.

. Um olhar sobre o bullying escolar e sua superação: contribuições da psicologia moral. In: TOGNETTA, L. R. P.; VINHA, T. P. (Org.). Conflitos na instituição educativa: perigo ou oportunidade? Campinas, SP: Mercado de Letras, 2011. p. 135-158.

TOGNETTA, L. R. P. Et al. Um panorama geral da violência na escola - e o que se faz para combatê-la. Campinas, SP: Mercado de Letras, 2010.

TOGNETTA, L. R. P.; VINHA, T. P. (Org.). Conflitos na instituição educativa: Perigo ou oportunidade? Campinas, SP: Mercado de Letras, 2011.

VINHA, T. P. Et al. A implantação da justiça restaurativa como um processo de resolução de conflitos na escola: uma realidade a ser construída. In: TOGNETTA, L. R. P.; VINHA, T. P. (Org.). Conflitos na instituição educativa: perigo ou oportunidade? Campinas, SP: Mercado de Letras, 2011. p. 265-302. 